\title{
SOCIAL IMPACTS ON DEVELOPMENT OF RURAL RIVER TRANSPORTATION IN INDONESIA
}

\author{
CHAIRUL INSANI ILHAM ${ }^{1 *}$, WINDI NOPRIYANTO ${ }^{2}$, DOHARMAN LUMBAN TUNGKUP ${ }^{3} \&$ \\ ARMAN HARAHAP ${ }^{4}$ \\ ${ }^{1,2,3}$ Polytechnic of Inland Waterways and Ferries Transport of Palembang, Human Resources and Development Agency, \\ Ministry of Transportation of Indonesia, Indonesia \\ ${ }^{4}$ Fakultas Pendidikan Keguruan dan Ilmu Pendidikan Universitas Labuhanbatu, Indonesia
}

\begin{abstract}
Indonesia is a maritime country that consists of thousands islands connected by seas and other type of inland water such as rivers, lakes, swamps and canals. Basically, water transportation particularly river transportation becomes one of the most important transportation modes to connect one area to another area because the absence of the availability of land transport infrastructure. Besides that, river transportation is the major transport mode in rural area where there is no a feasible transport mode to support their daily activities. However, the development of river transportationin rural area gives social impacts not only for people who live in rural area, but also for the area development itself as a whole. Those impacts influence people's life in many aspects such as education, health, environment, culture and even political system. Then, this paper presents social impacts caused by the development of rural river transportation that case study in Indonesia. Furthermore, the integrated and participatory approach is required to optimize the development of rural river transportation in Indonesia
\end{abstract}

KEYWORDS: Rural River Transportation,Social Impacts,Integrated and Participatory Approach

Received: May 13, 2020; Accepted: Jun 03, 2020; Published: Aug 04, 2020; Paper Id.: IJMPERDJUN2020604

\section{INTRODUCTION}

Rural area tends to be vulnerable to transportation issues becase more than two-thirds of the poor in the world live there (Todaro \& Smith, 2006). Additionally, the poor generally are lower income and they are only have one vehicle and/or even they do not have (Kumaretal., 2004). Besides that, the limited access for health service, education,employment (job opportunity) and other services becomes one of the major issues in the world (Velaga, et al., 2012). In general, the existing rural river transportation services is inadequate, for example a small and old transport fleet, a high transportation cost that cannot be covered for lower income, lack of proper safety standardsand still dependent on motorcycles and bicycles (Starkey, 2007). Using Rural Access Index, it is estimated that 900 million rural residents particularly the poor in developing countriesexperience problems to the transport access. Consequently, they need to spend a long travel time in travelling in order to comply their daily basic needs (Roberts, et al., 2006), in which lack of transport facilities induce rural areas become isolated (Parikesit \& Maghribi, 2005).

Actually, local governments reduce the poverty rate in rural area by focusing on the infrastructure development, especially road infrastructure (Starkey, 2007).In addition, the road infrastructure development, particularly in urban area, indeed, will improve the accessibility and economy development, but this way cannot be applied in the rural area in which it will lead to increase of motor vehicles usage and the road infrastructure 
development alone will not comply the transportation needs for rural communities (Dingen, 2000).

In watery countries such as Indonesia, road access cannot reach the rural areas, so the role of inland water transportation is very important to serve the accessibility of passengers and/or goods in the isolated areas (Parikesit, et al., 2003). However, nowadays, the inland water transportation in Indonesia is ironically ignoredand it has not been given the priority because of the dominance of the motor vehicle usage on the roads (Czuczman, 2004). It also comes up a lot of problems, for example, in Banjarmasin (South Borneo), the number of river vessels and navigable river length are continuously decreasing. Meanwhile, in Palembang (South Sumatra), the modes share for river transportation is only 3.75\%. In addition, the Musi River has a large tidal range so it is not navigable at all times (Susantono, 2013).In other locations, some river channels have eroded due to the movement of the ship (Sugeng, 2010) and experienced severe sedimentation problem (Kusdian, 2011).

Moreover, water transportation has a poor safety condition due to the excessive load and the lack of infrastructure support and it also identically leads to the poor and the isolated communities. Furthermore, in some regions in Indonesia, water transportation, particularly river transportation experience the extinction due to the lack of government concern and the poverty issue. In relation to this, it emerges the impacts on the isolated rural communities's welfare and it is vulnerable to the attainment of sustainable transportation that characterized by the lack of integrated transportation and the ignorance in transport planning (Czuczman, 2004).Therefore, in relation to those issues, this paper will explore the social impacts on the rural river transportation development in Indonesia particularly associated with sustainable transportation development and provide recommendations to improve rural river transportation system in Indonesia in relation to the impacts.

\section{RIVER TRANSPORT CHARACTERISTICS}

River transportation has a similar characteristics to railways transportation where it can only serve catchment area along the river channel. Usually, river transportation activity is managed traditionally without a fixed route and regular schedule. Besides that, its vehicle or river transportation ship is generally constructed from differentvariations of wood (Ministry of Transportation of Indonesia, 2007). River transportation has some potential advantages compared to the other transport modes. A commercial modern water transportationcan reliably serve passengers and/or goods with a low pollution and scheduled activity (Park and Nam, 2005). In addition, in the environmental perspectiveriver transportation actually supports the sustainable transportationin term of ecological and economic aspectsbecause it is efficient on the fuel consumption and environmental friendly (Sarma, 2010). Moreover, in economic perspective, the needs of river transportation infrastructure, particularly in the maintenance cost is about $20 \%$ of the road maintenance cost (Akanda, 2003). In a natural area, the needs of building a new river transportation infrastructure is not necessary except the quay unloading. For example, in India case, for the same transportation path length, the cost for developing river transportation is only about $5 \%-10 \%$ compared to the cost for developing four-lane road or building the railway network.

The development of river transportation is also important for the preservation of cultural and tourism development because the early civilization of many cities livesadjacent to the river (Hanh, 2006). Compared to another country, the river transportation modes in Indonesia is better due to its capacity can load a large quantities of goods with relatively small environmental impact (Susantono, 2013). Additionally, river transportation also provides an alternative solution for reducing traffic congestion and road damage (Ministry of Transportation of Indonesia, 2007). 
Literally, rural area is isolated and the sparsely populated area. The rural development usually depends on the existing natural resource-based industries. The distance to reach the market centre makes the rural areasis less preferable for both residentsand industries, in which they do not involve the fabrication process.Nowadays, there is a very noticeable difference between rural and urban transport. This gap is caused as the impacts of inequitable development target undertaken by the government. As the result, the access for rural communities is slower than the urban communities. Whereas, for example, the agricultural products from rural area is needed to other areas, in which it needsthe river transportationfor distributing them. Consequently, if the river transportation system are not able for distributing process, the development of rural area will be hampered (Hensi Margaretta, 2000).

Another thingon the transportation problem between rural and isolated areas is the connectivity. The government needs to give more attention in providing the infrastructure among them (Susantono, 2013) because it relates to the social interaction. In addition, rural area is a place where social phenomenaoccurred between both rural and the isolated areacommunities(Currie et al., 2010).It means that the limitations of accessibility in rural areas can induce the problems in providing facilities and services to other areas, such as health, education, employment, water supply and fuel resources. The presence of the access to health care, education, employment and other facilities and services, such as shopping centres for individuals who live and work in rural areas has been a major issue all over the world. Physical and virtual connectivity that is also reinforced by limited development activities. Besides that, rural communitieshave to face the problems related to accessibility; physical and virtual connectivity that those are also reinforced bythe limited development activities.Consequently, it leads to the disparities between rural and urban communities.

\section{DISCCUSSIONS}

\subsection{The Issues of Rural River Transportation in Indonesia}

Currently, the majorconcern of transportation in Indonesia relates to the road transportation that serves $90 \%$ passengers and/or goods's movement and one the one hand, it becomes the primary choice for short and medium trips within the island (Susantono, 2013).On the other hand, the rapid growth of activity in transport modes like road and railtransport providesthe negative externalities in various sectors such as socio-economic, health and even social welfare.

Indonesia is a country that dominated by water. Its water area is around 7.9 million $\mathrm{km}^{2}$ (Parikesit, et al., 2003) compared to the total area of 9.8 million $\mathrm{km}^{2}$. It also consists of many inland waters such as rivers, lakes, swamps and canals all of which are potential for transport infrastructure where the length of 214 rivers are navigable along 23,255 kilometers (Ministry of Transportationof Indonesia, 2013). In relation to this, Indonesia has a large potential on inland waters and it was placed as seventh ranked all over the world and third ranked in Asia (CIA, 2013).

Inland waters, especially rivers, also plays a vital role for the balance of ecosystem such as reservoirs and flood control channel (Ministry of Transportation of Indonesia, 2013) The role of inland water transportation is very important, especially for rural and the isolated areas which are not covered by road transport network (Parikesit, et al., 2003). The river is a transportation infrastructure that can be accessed toreachthe isolated areaswhich cannot be provided by other transport modes (Susantono, 2013). This condition makes the waters of rural areas is closely related to the issue of sustainable transportation.

In the economic perspective, inland water transportationtakes a vital role to support the rural agriculture and industry because some areas cannot be reached by road transportation. In addition, the water infrastructure network is less due to the 
natural condition. It tends to stagnate or even decrease (Parikesittet al., 2003). For example, Banjarmasin that known as "The City of a Thousand Rivers", the navigable length river and the number of shipsare decreasing. Meanshile, in Palembang (South Sumatra),the river transportation only uses 3.75\% of the total amount of river length. Additionally, the Musi River located in Palembang has the limitation on the tidal ranges which is not navigable for all times (Susantono, 2013). On the other hand, inland waters transportbecomes less attractive for consumera because ofa low speed compared to the road transport (Sarma, 2010).

In the social perspective, inland waterstransport servedin rural areas is very important because this region is generally synonymous with poverty and backwardness. However, rural population in the worldreaches 3.1 billion or 55\% of the world population and at least 70\% is the poor population who live in rural areas (IFAD, 2010). The same condition also occurs in Indonesia, in whichin the period of March 2013 the poverty rate inthe village is $14.32 \%$ and $8.39 \%$ in urban areas (CBS, 2013).Thus, $63.2 \%$ of the poor population in Indonesia livein rural areas. This evidence is also supported by the existence of backward villages without the access of road network except inland waters transport. One of backward villages is located in South Sumatraas shown in Figure2 (blue line colorshows the inland water network which covers almost all areas).

River transportation is an old transport modes that can be categorized as the traditional transportation in Indonesia, particularly in Sumatra, Kalimantan and Papua where people mainly use river transportation to travel outside from the isolated area (Susantono, 2013). In the case of Jambi city, river transportation was the first transport mode that connected Jambi city to the CBD area (central business district) located in the north side of the river. By historybefore 1975, river transportationis used to utilize the river stream to travel from one place to another placeby using very traditional rowboat. In 1976, the traditional boats began using machine, so the river transportation became easier. Over 1986, the government developed the roads and bridges to connect among regions that separated by the river (the bridge construction between Aurduri Bridge 1 and Bridge Batang II).

Inland waters transporttends to the decrease every year. Banjarmasin was one of the city that harness rivers as a spearheadin their daily activities. In 1970, the river was crowded and reached almost the entire territory. Unfortunately, the length of navigable rivers and a number of river transport continually decrease along the development of road transport. Meanwhile in the West Borneo society (Kalimantan) also utilizesthe Barito river as an effective transport modefor distributing goods. The Barito river is including a large river, somany freight transport activities use this river as transport mode to transport the forest products, to fulfill the community's needsand othersutilities. (Mukti, 2010). Furthermore, lack of the transportation access, especially for low-income people who do not live in urban areas makethem vulnerable to the social exclusion because they cannot participate in social activities due to they do not have the private vehiclethat need to spend a large money for investment and operational costs(Currie et al., 2010).

In the environmental perspective, inland waters transport relates to the sustainable transportationbecause it is efficient in using the fuel consumption (Sarma, 2010). Different impacts observed in some countries like Central Europe (Mihica, et al., 2011), China, and South America (Haydee Pizarro, 2007) where water is polluted as the result of river transportation. Another problem in river transportation is the fluctuating water level (Jonkeren, et al., 2007) or the silting up of the river (SB Dai, 2009) which cannot be controlled. 


\subsection{Social Impacts of Rural River Transportation in Indonesia}

Social Impact Assessment (SIA) is one of the important parts in the development of transportation sector. As Vanclay (2012) states that social impact assessment is the process of analysing, monitoring and managing all impacts of the planned intervention (projects, plans, policies and programs)on individuals and communities both interaction with their surroundings by incorporating stakeholder analysis, public participation and community engagement. The aim of the SIA process is to develop an effective and adaptive management and to enhance some strategies to create more sustainable and equitable biophysical and human environment (Vanclay,2003; Vanclay,2012).So, people will impose and obtain both positive impacts (benefits) andnegative impacts (costs) of any public or private actions in order to improve their quality of live (Interorganizational Committee, 1994).

The facts mentioned above show that Indonesia has a large number of inland water placed as $7^{\text {th }}$ rank all over the world, in which river sector plays an important role to distribute people and/or goods. One of the challenges of this river transportation is to decrease the isolated areas where people are still in there. This becomes the impediments to develop the rural river transportation for the future. Indonesia is well-known to have big amounts of islands and rivers, water transportation is considered to be an important part for connecting one rural area either to other areas or Centre Business District (CBD) because of the absence of land transport infrastructure.Some rural areas have already had the river transportationand even with the minimum facilities and some of them are totally isolated area and do not have any access to another places.

In relation to those, there are three kinds of social impacts caused by the development of rural river transportation in Indonesia. First impact is education. Children and young people in rural area often do not get a proper education due to the lack of transportation access, in which the education facilities (e.g. school, library, books, internet access etc.) is limited. Regarding with the fulfillment of those facilities inevitably needs the rural river transportation to transport the resources. People who live in rural area have to get a better chance to improve their education through developing the rural river transportation.Consequently, if the needs of transportation is fulfilled, it will impact on the rural development as a whole (e.g. economic development, the tourism development etc.).

The second impact of developing the rural river transportation is related to the health issue. Lack of health facilities in rural area enforce people to find a better health facilities. Some people concern about their health because it relates to the social welfare to conduct their daily activities. Vanclay (2003) stated that "health is a state of complete physical, mental, social and spiritual wellbeing and not merely the absence of disease or infirmity". Therefore, peoplewho more concern on their health will care about many aspects in their life sucha as the air quality, food, waterand sanitary because those takean important parts in relation to the health issue.

The last impacts (but not least the social impact) is in politicalperspective.As democratic country that need the legitimacy from all citizend, the rural people also have rights to participate in planning arena in order to develop their country. Although they live in rural and isolated area, they are also needed to convey their opinions particularly in president and vice president general election. The development of rural river transport is required to connect the interaction relationship between urban, rural and the isolated area in making dialogue or discussion on the political issue. In relation to those impacts, according to the result of the Sustainability Mobility, Policy Measures and Assessment (SUMMA) funded by the European Commission's Directorate General for Energy and Transport in 2010, there are several indicators on social impact for sustainable transportdevelopment that can be used for assessing and evaluating the social impacts development of rural river 
transport in Indonesia.

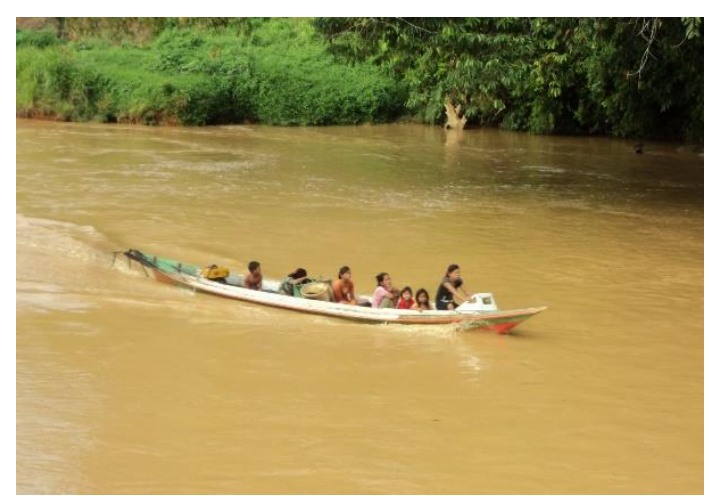

Figure 1: Rural river transport in Indonesia

Table 1: Social impact indicator of sustainability transportation

\begin{tabular}{|c|c|c|}
\hline No. & Aspect & Indicators \\
\hline 1. & $\begin{array}{l}\text { Accessibility and affordability } \\
\text { (for users) }\end{array}$ & $\begin{array}{ll}- & \text { Access to basic public services } \\
- & \text { Access to public transportation } \\
- & \text { Independence from the vehicle } \\
- & \text { Affordability } \\
- & \text { The length of the trip }\end{array}$ \\
\hline 2. & $\begin{array}{l}\text { Security and safety (users, } \\
\text { drivers and affected parties) }\end{array}$ & $\begin{array}{ll}- & \text { Accidents with deaths and serious injuries } \\
- & \text { Vehicle theft and other crime } \\
- & \text { Public transport security }\end{array}$ \\
\hline 3. & Health and fitness (users) & $\begin{array}{l}\text { Walking and cycling as a means of transportation for short } \\
\text { distance travel }\end{array}$ \\
\hline 4. & $\begin{array}{l}\text { Leisure life and public facilities } \\
\text { (population of residents, } \\
\text { community and affected parties) }\end{array}$ & $\begin{array}{ll}- & \text { Facilities for walking and comfort for pedestrians } \\
- & \text { Facility to slow down the speed of traffic (traffic } \\
\text { calming) } & \\
- & \text { Travelling children to school } \\
- & \text { Availability and accessibility to open space }\end{array}$ \\
\hline 5. & $\begin{array}{l}\text { Equity (users, drivers and } \\
\text { affected parties) }\end{array}$ & $\begin{array}{ll}- & \text { Horizontal equity (fairness) } \\
- & \text { Vertical equity (earnings) } \\
- & \text { Vertical equity (needs and mobility) }\end{array}$ \\
\hline 6. & $\begin{array}{l}\text { Social Cohesion (population } \\
\text { occupants, and affected parties) }\end{array}$ & $\begin{array}{lc}- & \text { Profile of public opinion on the issue of transport and } \\
\text { transport policy } \\
- & \text { Violation of traffic rules } \\
- & \text { Remotely trip on workers commuting (commuting) }\end{array}$ \\
\hline 7. & $\begin{array}{l}\text { The working environment in the } \\
\text { transport sector (workers, } \\
\text { drivers and operating personnel) }\end{array}$ & $\begin{array}{ll}- & \text { Work accident } \\
- & \text { Risky working conditions are not safe } \\
- & \text { Absence from work due to an accident and illness }\end{array}$ \\
\hline
\end{tabular}

Source: SUMMA adopted in Hardy (2011)

The social impact indicators for the rural river transportation in Indonesia is very important in order to solve the backwardness and some obstacles on rural river transportation. It is also important to monitor and evaluatethe rural river transport in term of development because there are a lot of the isolated rural areas in Indonesia which rely on the river as the only accessible transport mode.

\subsection{Recommendations to Improve Rural River Transportation in Indonesia}

After explaining about some social impacts caused by the development of rural river transportation, the author will provide 
some recommendations to maximize the benefits. First of all is in term of infrastructure development. Port or pier have to be built in every rural area to improve the access to another places. Besides that, for a long-term goal, the integrated transportationsystem (e.g. integration between rural river transportation and land transportation) have also to be be employed to makemore effective and efficient in time and resources. In doing so, the infrastructure development have to involve the rural community (participatory approach), in which they can be empowered (e.g. skills and expertise that they have) such as the can be laborers. This way can improve the social welfare because reduce the unemployment and increase job opportunity.

The second suggestion is improve the quality of transport modes (vehicle). The current shipused in some rural areas in Indonesia is often made by wood and there is no the maintenance process or renewal for the old ship. The old ships operated still neglectabout the safety issue for passengers. In relation to this, the ship has to be designed welldone based on the focus on the fullfillment of technically safety standardsand the capacity of passengers. Although rural river transport accident rate is relatively low, but this have to be concerned because of the limitation of passenger safety equipment (Mukti, 2010). Besides that, the supply of facilities in inland water transport have to accommodate the needs of older people and disable persons (Parikshit, et al., 2003). In response to this, involving rural community through educative programs in order to improve their knowledge, skills and expertise to create and design a better ship, is also needed. This way not only create the benefits for rural community, but also it relates to be an independent rural area that do not depend on the urban area because rural area also have the resource particularly human resource that also have to be developed for the future.

The last suggestion deals with the funding support to finance the rural river transportation infrastructure development and to improve the educative programs for rural community. In response to this, involving all stakeholders through making collaborative action between government in all level (national/province/local), private sectors through Corporate Social Responsibility (CSR), non-governmental organization/NGO and making agreements to develop the rural area (e.g. PPP/public private partnership) are required. As Prayudantoet. al. (2013) state that funding is one of the problems in developing the transportation system in Indonesia. So, in relation to funding, the government do not depend on national/province/local budgets.

\section{CONCLUSIONS}

The rural area development in Indonesia in term of the supply of resources for other areas (e.g. providing the agriculture products), the increasing an aesthetic value (e.g. potential for tourism development), the benefits for the surroundings ecosystem and the benefits for environment and also economic development, actually, is merely supported by the existence of rural river transportation that have to be connected between rural area and the isolated area. The development of rural river transportation brings the social impacts are the increasing the accessibility that people who live in rural area will get a more access; the improvement of education and health facilities and its services; and in term of political perspective that rural people can also participate in democracy arena that they have the rights on addressing their voice and notion for their country to improve the legitimacy in polical domain. Those impact will infuence the attainment of sustainable transportation development not only for rural area but also for other area in Indonesia as a whole. Thus, in relation to this, the needs of integrated approach and participatory approach of the planned interventions (projects, plans, policies and programs) that involve all actors (government, private sectors, NGO, rural communities and other parties) is required in order to achieve 'sustainable rural development' for the future.

\section{REFERENCES}


1. Akanda, A., 2003. Inland Water Transport Development in India : The Role of ADB. Chennai: SUMINFRA : Summit on Integrated Infrastructure Development in Southern Region.

2. BPS (Centra Bereau of Statistics), 2013. Profil Kemiskinan di Indonesia Maret 2013, Jakarta: Badan Pusat Statistik.

3. CIA, 2013. Central Intelligence Agency. [Online] Available at: https://www.cia.gov/library/publications/the-worldfactbook/rankorder/2093rank.html [Accessed 15 January 2014].

4. Currie, G. et al., 2010. Investigating Links Between Transport Disadvantage, Social Exclusion and Well-being in Melbourne Updated Results. Journal of Research in Transportation Economics, Elsevier, Volume 29 (2010), p. 287-295.

5. Czuczman, K., 2004. Waterways and Livelihodds : Journey to the Mainstream?. s.l.:International Forum for Rural Transport and Development (IFRTD).

6. Dingen, R., 2000. A Guide to Integrated Rural Accessibility Planning in Malawi, Harare, Zimbabwe: the International Labour Organisation.

7. Hanh, Vu Thi Hong, 2006. Canal-side Highway in Ho Chi Minh City Vietnam - Issues of Urban Cultural Conservation and Tourisme Development. GeoJournal, Vol. 66, pp 165-186

8. Hensi Margareta. 2000. Perbaikan Sistem Transportasi di Perdesaan di Era Otonomi Daerah. Makalah Geografi Transportasi Fakultas Geografi UGM

9. Hardy, D. K., 2011. Sustainability 101: A Primer for ITE Members. Institute of Transportation Engineering Journal.

10. Haydée Pizarro, P. R.,. S. M. B.,. I. O. \&. I. I., 2007. The sudestadas: a hydro-meteorological phenomenon that affects river pollution (River Luján, South America),. Hydrological Sciences Journal, Volume 52:4, pp. 702-712.

11. Interorganizational Committee (IC), 1994. Guidelines and Principles For Social ImpactAssessment. Available: http://www.nmfs.noaa.gov/sfa/social_impact_guide.htm. Last accessed 10th June 2015.

12. IFAD, 2010. Rural Poverty Report 2011, Roma: International Fund for Agricultural Development (IFAD).

13. Jonkeren, O., Rietveld, P. \& van Ommeren, J., 2007. Climate Change and Inland Waterway Transport : Welfare Effects of Low Water Levels on the river Rhine. Journal of Transport Economics and Policy, Volume Volume 41, Part 3, September 2007, p. $387-411$.

14. Kemenhub (MoT), 2007. Studi Penyusunan Rencana Transportasi Perairan Regional Sulawesi, Jakarta: Direktorat Jenderal Perhubungan Darat.

15. Kemenhub (MoT), 2013. Konsep Cetak Biru Angkutan Sungai dan Danau, Jakarta: Direktorat Angkutan Sungai, Danau dan Penyeberangan.

16. Kemenhub (MoT), 2013. Perhubungan Darat Dalam Angka 2012. Edisi IX Maret 2013 ed. Jakarta: Direktorat Jenderal Perhubungan Darat.

17. Kumar, C. P., Basu, D. \& Maitra, B., 2004. Modeling Generalized Cost of Travel for Rural Bus Users : A Case Study. Journal of Public Transportation, Volume Vol. 7, No. 2, pp. 59-72.

18. Kusdian, D., 2011. Potensi Revitalisasi Transportasi Sungai di Provinsi Lampung. Jurnal Transportasi, Volume 11 No 2, pp. 143-152.

19. Lucas, K., 2011. Making the Connections between Transport Disadvantage and The Social Exclusion of Low Income Populations in The Tshwane Region of South Africa. Journal of Transport Geography, Volume 19 (2011), pp. 1320-1334.

20. Mihica, S., Golusin, M. \& Mihajlovic, M., 2011. Policy and promotion of sustainable inland waterway transport in Europe - 
Danube River. Renewable and Sustainable Energy Reviews, Volume 15, p. 1801-1809.

21. Mukti, E. T., 2010. Kajian Preferensi Moda Angkutan Barang Antara Truk Dan Angkutan Sungai Pada Pergerakan Di Sungai Kapuas Kalimantan Barat. Jurnal teknik sipil untan, volume volume 10 nomor 2 - Desember 2010, pp. 317-330.

22. Parikesit, D., Kushari, K. \& Novitarini, R., 2003. The Characteristics Of Rural Water Transport:Case Studies Of Three Provinces In Indonesia. s.l., Eastern Asia Society for Transportation Studies, Vol.4, October, 2003.

23. Parikesit, D. \& Maghribi, L. O., 2005. Development of A Dynamic Model for Investigating The Interaction Between Rural Transport and Development : A Case of Southeast Sulawesi, Indonesia. Journal of the Eastern Asia Society for Transportation Studies, Volume 6, pp. 2747-2761.

24. Park, Dongjoo and Nam, Doohee, 2005. Strategies Enhancing Water Transportation Using Econometric Model Approach. Journal of the Eastern Asia Society for Transportation Studies, Vol. 6, pp 825-827

25. Prayudyanto, M,N., Jinc, A., Belka, S., 2013. Role of Urban Public Transport Subsidy in Indonesia. Proceedings of the Eastern Asia Society for Transportation Studies, Vol.9.

26. Roberts, P., KC, S. \& Rastogi, C., 2006. Rural Access Index: A Key Development Indicator, Washington, DC: The International Bank for Reconstruction and Development/The World Bank.

27. S. B. Dai, S. L. Y. \&. M. L., 2009. The sharp decrease in suspended sediment supply from China's rivers to the sea: anthropogenic and natural causes. Hydrological Sciences Journal, Volume 54:1, pp. 135-146.

28. Sarma, K., 2010. India's National Waterway : A Log way to Go. RITES Journal, July 2010, pp. 2301-2316.

29. Starkey, R., 2007. Rural transport services in Africa : Lessons from rapid appraisal surveys in Burkina Faso, Cameroon, Tanzania and Zambia, s.l.: The World Bank - Africa Region.

30. Susantono, B., 2013. Transportasi \& Investasi : Tantangan dan Perspektif Multidimensi. Pertama ed. Jakarta: Penerbit Buku Kompas.

31. Susantono, B. et al., 2004. 1-2-3 Langkah : Langkah Kecil Yang Kita Lakukan Menuju Transportasi Yang Berkelanjutan. Jakarta: Masyarakat Transportasi Indonesia.

32. Todaro, M. \& Smith, S. C., 2006. Pembangunan Ekonomi. 9 ed. Jakarta: Penerbit Erlangga.

33. Vanclay, F. (2002) Conceptualizing Social Impacts. Environmental Impact Assessment Review.

34. Vanclay, F. (2003). SIA principles-International Principles For Social Impact Assessment. Impact Assessment and Project Appraisa. 21 (1), p5-11.

35. Vanclay, F. (2012). The potential application of social impact assessment in integrated coastal zone management. Ocean \& Coastal Management. 68,p149-156. ,p149-156.

36. Velaga, N. R. et al., 2012. Transport Poverty Meets The Digital Divide : Accessibility and Connectivity in Rural Communities. Journal of Transport Geography, Volume 21, pp. 102-112. 

